\title{
How Exchange Rates Are Determined
}

\begin{abstract}
A discussion of the foreign exchange value of the U.S. dollar will be high on the agenda in the upcoming Williamsburg Economic summit, at which President Reagan will host the heads of government of the major industrial democracies. Heightening its importance is the fact that the rising tide of protectionism in the U.S. is directly related to the sharp appreciation (by almost 20 percent) in the value of the dollar in the last two years. This appreciation in the exchange rate reflects current developments in monetary and fiscal policy in the U.S. and in other countries. Specifically, the combination of large U.S. structural government deficits and a highly credible monetary policy intent on not financing those deficits through money creation and inflation are prominent reasons for the movements in exchange rates. The purpose of this Letter is to explain that relationship.
\end{abstract}

\section{Determining exchange rates}

An exchange rate is the price of one currency in terms of another currency. As such, the exchange rate should be analyzed in the same way as the price of any "good" - in terms of its supply and demand. In the case of the exchange value of the dollar, the international supply of dollars is provided by American residents who wish to purchase foreign goods, services, and financial assets (like stocks and bonnds). The international demand for dollars is provided by foreign residents who wish to purchase U.S. goods, services, and financial assets.

The net result of all these transactions is called the (international) balance of payments and can be divided into two categories: a balance of trade in goods and services called the "current account," and a balance of financial asset flows called the "capital account." The foreign exchange value of the dollar ultimately must be such that there is a sustainable balance in each of these accounts. For the current account, this condition is known as "purchasing power parity"; the condition for the capital account is known as "interest rate parity."

Purchasing Power Parity (PPP). In the long run, the exchange rate is determined by the: international supply and demand for goods and services. A key determinant of this international balance in the goods market is called purchasing power parity (PPP). The term refers to the rough equality that must exist between the domestic purchasing power of a currency and its international purchasing power. In Chart 1, PPP is measured by the ratio of wholesale prices in the U.S. to a weighted average of those of 15 of its major trading partners. The effective exchange rate is measured by the value of the dollar against the currencies of these same 15 countries.

When the exchange rate is above PPP the currency can be considered "overvalued." This means that the dollar buys more goods abroad than at home. Consequently, Americans will find it cheaper to purchase foreign goods. At the same time, foreign residents will find U.S. exports more costly than their own domestic goods. The result will be a surge in imports and a decline in exports that will lead to a decline in the trade balance of the U.S. The decline in trade balance will reduce the international demand for dollars and, eventually, depreciate the exchange rate.

This process takes time because both exporters and importers respond slowly to changes in their prices and changes in the exchange rate. As a result, if a gap emerges between the exchange value of the dollar and its purchasing power parity value, that gap may last for some time. To a large extent such gaps emerge because of changes between interest rates in the U.S. and those abroad.
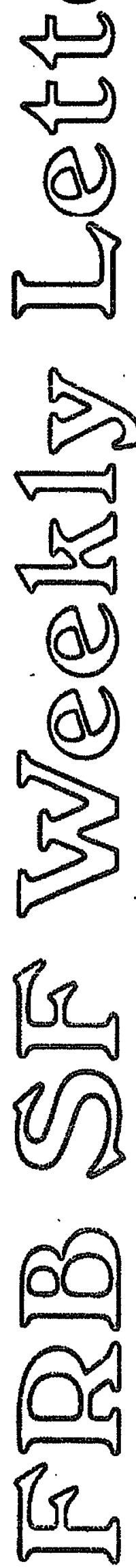
Opinions expressed in this newsletter do not necessarily reflect the views of the management of the Federal Reserve Bank of San Francisco. or of the Board of Governors of the Federal Reserve System.

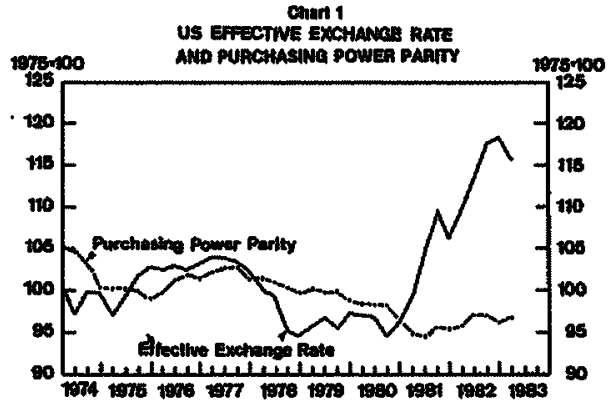

Interest Rate Parity. In the very long run, it is assumed that inflation-adjusted, or real, interest rates in different countries depend fundamentally on the productivity of capital in those countries. Capital will eventually move from low to high productivity countries, making interest rates across countries roughly equal. However, in the short- to intermediate-run, real interest rates can vary between countries, and this variation can explain much of the gap between exchange rates and purchasing power parity that has emerged in recent years.

A rise in real interest rates in the United States relative to the rates abroad creates profit opportunities for foreign residents who purchase U.S. assets. These incentives will continue to operate until the percentage appreciation in the exchange value of the dollar equals the rise in U.S. interest rates. This exchange rate response to a change in interest rates will be immediate because asset markets respond quickly to changes in interest rates and exchange rates. ${ }^{*}$

The duration of the rise in real rates is important in determining how much the exchange rate will appreciate, because the exchange: rate must appreciate enough to offset the total increase in interest earned. The longer the duration, the greater the impact on the exchange rate. For example, a one percentage point annual increase in a five-year investment represents five times more additional interest than the same increase in the yield on a one-year security. Thus, a one

*Only a rise in real interest rates will attract capital and appreciate the exchange rate. If the rise in interest rates is simply due to a rise in inflation expectations in the U.S., it will not appreciate the dollar. Indeed, a rise in inflation expectations could have the opposite effect. Thus, a change in nominal interest rates can be associated with rises or falls in the exchange value of a currency depending upon whether the differentials are due to a change in real rates or a change in inflation expectations. percentage point increase in the real rate of a one-year investment leads to a one percentage point increase in the exchange rate, and a one percentage.point increase in the real rate of a 5 -year security leads to a 5 percentage point increase in the exchange value of the dollar today.

In recent years, these term structure considerations have been especially important in determining the effects of real interest rates on the exchange rate. The extraordinary overvaluation of the dollar in the last two years suggests that not only have short term U.S. real rates increased but that intermediate-term real rates have risen as well.

\section{The particulars}

The relationship between movements in the exchange value of the dollar and purchasing power parity in the long run, and between those movements and interest rate parity in the short-run, are evident in the bilateral exchange rate between the U.S. and individual foreign countries. In Charts 2 and 3, we illustrate these relationships with the Swiss franc and the Italian lira. Switzerland and Italy have followed sharply different macroeconomic policies over the last decade.

Switzerland's inflation rate has been substantially below that of the U.S. and, as a result, its wholesale prices have declined relative to wholesale prices here. The relative decline implies a fall in the purchasing power of the U.S. dollar relative to the Swiss franc. The exchange value of the dollar declined roughly in line with the decline in purchasing parity of the dollar against the Swiss franc until 1980, when the dollar became sharply overvalued.

Italy has, on average, followed a policy allowing higher inflation than the U.S. over the last decade. As a result, Italian wholesale prices have risen on average relative to U.S. wholesale prices, and the relative rise has implied an increase in the purchasing power of the U.S. dollar compared to the lira. The exchange value of the dollar relative to the 


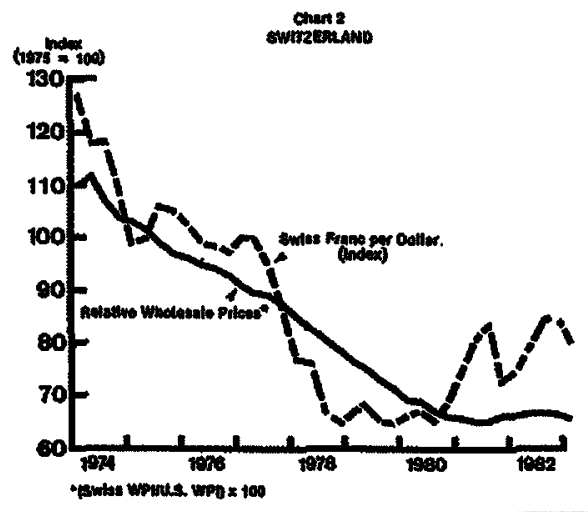

Italian lira.appreciated roughly in line with its rising purchasing power until 1980 . Subsequently, during the period 1981-1982, the dollar also rose substantially above its purchasing power parity level versus the Italian lira.

The dollar is now approximately 25 percent overvalued with respect to both the Italian lira and the Swiss franc. Again, the reason for the overvaluation is the extraordinarily high level of our real interest rates. The two examples illustrate the fact that the long-run trend in the value of the dollar relative to individual currencies will depend on differences in inflation. However, the short-run value of the dollar versus the same currencies will depend upon the relationship between U.S. real interest rates and real interest rates in those countries.

\section{Deficits and dollars}

A major reason for the rise in real U.S. interest rates in the last two years has been the emergence of structural budget deficits in the U.S. These are deficits that will not decline as the economy recovers. Interest rates today on 7- to 10-year securities will be influenced by expectations of structural deficits over the next 7 to 10 years. Thus, future deficits can affect today's real longterm interest rates. These higher interest rates not only help mobilize domestic savings to purchase government debt, they also encourage foreign residents to purchaseU.S. assets and thus induce a large capital inflow. This increased demand for dollars is a major reason for the appreciation of the dollar to a level well above its purchasing . power parity value in the last two years.

Our internationally traded goods industries (such as autos, steel and agriculture) feel a

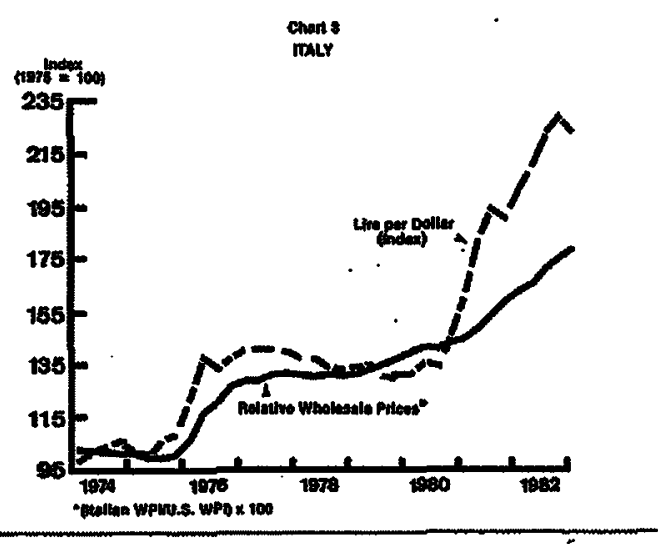

double impact from government deficits. They not only find it difficult to raise funds for new investment because of competition from government borrowing, but they also see their export markets shrinking and imports making greater inroads into their domestic market. The emergence of protectionist pressure in the United States is undoubtedly related to the overvalued dollar.

\section{Policy solutions}

Public policy can take only two routes to eliminate the overvalued dollar. The first would be to eliminate structural deficits. This would take the pressure off U.S. real interest rates, reduce the incentive for foreign residents to purchase U.S. assets, and permit the exchange value of the dollar to move back to its purchasing power parity value. The second alternative would be for monetary policy to accommodate budget deficits by increasing money growth. This would undoubtedly raise long-run inflation expectations and probably lower long-term real interest rates, at least temporarily. The result could be a precipitous decline in the exchange value of the dollar that perhaps even undershoots purchasing power parity, as the exchange rate did in the late 1970s.

If neither monetary nor fiscal policy addresses the problem of an overvalued dollar, then the market will dictate its own solution. One solution is a shrinkage of our internationally traded goods industries in line with the overvalued dollar. An equally unpalatable solution is the imposition of various protectionist measures, but this would reverse the free trade traditions that have served the United States so well for the last 40 years.

Michael Keran
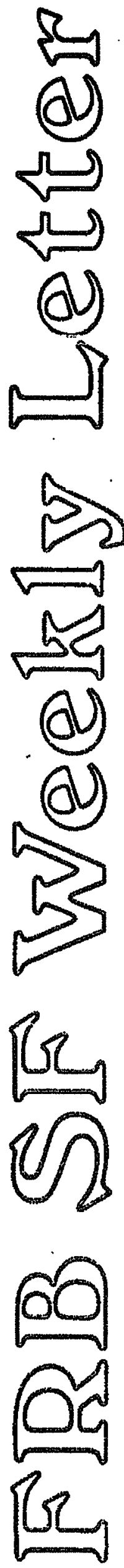


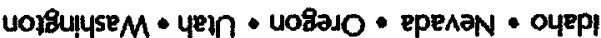

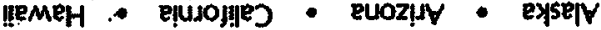

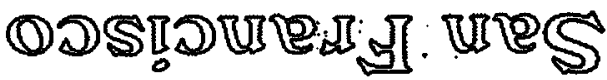

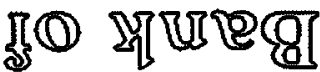

(এ)

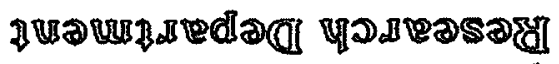

\section{BANKING DATA-TWELFTH FEDERAL RESERVE DISTRICT}

(Dollar amounts in millions)

\begin{tabular}{|c|c|c|c|c|}
\hline $\begin{array}{l}\text { Selected Assets and Liahilities } \\
\text { Large Commercial Banks }\end{array}$ & $\begin{array}{c}\text { Amount } \\
\text { Outstanding } \\
5 / 11 / 83\end{array}$ & $\begin{array}{c}\text { Change } \\
\text { from } \\
5 / 4 / 83\end{array}$ & 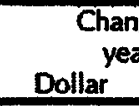 & $\begin{array}{l}\text { from } \\
\text { go } \\
\text { Percent }\end{array}$ \\
\hline $\begin{array}{l}\text { Loans (gross, adjusted) and investments* } \\
\text { Loans (gross, adjusted) - total\# } \\
\text { Commercial and industrial } \\
\text { Real estate } \\
\text { Loans to individuals } \\
\text { Securities loans } \\
\text { U.S. Treasury securities* } \\
\text { Other securities* } \\
\text { Demand deposits - total \# } \\
\text { Demand deposits - adjusted } \\
\text { Savings deposits - totalt } \\
\text { Time deposits - total\# } \\
\text { Individuals, part. \& corp. } \\
\text { (Large negotiable CD's) }\end{array}$ & $\begin{array}{r}162,764 \\
140,829 \\
44,971 \\
56,163 \\
23,547 \\
2,243 \\
8,035 \\
13,900 \\
40,452 \\
29,033 \\
65,998 \\
65,961 \\
59,156 \\
19,503\end{array}$ & $\begin{array}{r}-1,377 \\
-1,265 \\
=\quad 570 \\
=\quad 88 \\
-\quad 84 \\
=\quad 544 \\
=\quad 62 \\
=\quad 49 \\
-1,111 \\
\quad 728 \\
-\quad 372 \\
-\quad 393 \\
-\quad 381 \\
-\quad 166\end{array}$ & $\begin{array}{r}3,454 \\
2,373 \\
1,559 \\
-\quad 1,010 \\
230 \\
196 \\
1,987 \\
-\quad 907 \\
2,076 \\
2,397 \\
35,366 \\
-27,027 \\
-24,112 \\
-14,621\end{array}$ & $\begin{array}{r}2.2 \\
1.7 \\
3.6 \\
-\quad 1.8 \\
1.0 \\
9.6 \\
32.9 \\
-\quad 6.1 \\
5.4 \\
9.0 \\
115.4 \\
-29.1 \\
-29.0 \\
-42.8\end{array}$ \\
\hline $\begin{array}{l}\text { Weekly Averages } \\
\text { of Daily Figures }\end{array}$ & $\begin{array}{l}\text { Week ended } \\
4 / 20 / 83\end{array}$ & $\begin{array}{l}\text { Week ended } \\
4 / 13 / 83\end{array}$ & \multicolumn{2}{|c|}{$\begin{array}{c}\text { Comparable } \\
\text { year-ago period }\end{array}$} \\
\hline $\begin{array}{l}\text { Member Bank Reserve Position } \\
\text { Excess Reserves (+)/Deficiency (m) } \\
\text { Borrowings } \\
\text { Net free reserves (+)/Net borrowed( }- \text { ) }\end{array}$ & $\begin{array}{r}65 \\
2 \\
63\end{array}$ & $\begin{array}{r}147 \\
121 \\
26\end{array}$ & & $\begin{array}{r}104 \\
20 \\
84\end{array}$ \\
\hline
\end{tabular}

* Excludes trading account securities.

\# Includes items not shown separately.

+ Includes Money Market Deposit Accounts, Super-NOW accounts, and NOW accounts.

Editorial comments may be addresed to the editor (Gregory Tong) or to the author.... . Free copies

of this and other Federal Reserve publications can be obtained by calling or writing the Public

Information Section, Federal Reserve Bank of San Franclsco, P.O. Box 7702, San Francisco 94120.

Phone (415) 974-2246. 